\title{
Deneysel tirotoksikoz modelinde sıçan ovaryum dokusu rejenerasyon yeteneği ve kapasitesi
}

Thyrotoxicosis in experimental rat model of ovarian tissue regeneration capability and capacity

\author{
Fatih OLTULU ${ }^{1}$ Hüseyin AKTUĞ ${ }^{2}$ Ayşegül UYSAL ${ }^{2}$ Gülperi ÖKTEM ${ }^{2}$ Nevbahar TURGAN ${ }^{3}$ \\ Nefise Ülkü KARABAY YAVAŞOĞLU ${ }^{4}$ Altuğ YAVAŞOĞLU ${ }^{2}$ \\ ${ }^{1}$ Merkezefendi Devlet Hastanesi, Histoloji ve Embriyoloji Kliniği, Manisa, Türkiye \\ ${ }^{2}$ Ege Üniversitesi Tıp Fakültesi, Histoloji ve Embriyoloji Anabilim Dalı, İzmir, Türkiye \\ ${ }^{3}$ Ege Üniversitesi Tıp Fakültesi, Tıbbi Biyokimya Anabilim Dalı, İzmir, Türkiye \\ ${ }^{4}$ Ege Üniversitesi Fen Fakültesi, Biyoloji Bölümü, İzmir, Türkiye
}

\section{Öz}

Amaç: Bu çalışmada, deneysel olarak tirotoksikoz oluşturulan sıçanlarda, tirotoksikoza bağlı olarak ovaryum yapısında, özellikle tiroid hormon reseptörleri içeren oosit, kumulus hücreleri ve granülosa hücrelerinde oluşabilecek histolojik değişimler ile doku rejenerasyon yeteneği ve kapasitesinin, kök hücre belirteçleri açısından immünohistokimyasal olarak araştırılması amaçlandı.

Gereç ve Yöntem: Her biri 8 sıçandan oluşan 2 çalışma grubu oluşturuldu. Tirotoksikoz grubu dişi sıçanlara 10 gün intraperitoneal $500 \mu \mathrm{gr} / \mathrm{kg} /$ gün 3,3',5-Triiodo-L-thyronine enjekte edildi. On birinci gün tüm hayvanlara anestezi uygulandı, biyokimyasal değerlendirmeler için $5 \mathrm{cc}$ kan alındıktan sonra dekapite edilerek ovaryumları çıkarıldı. Ovaryumlar immünohistokimyasal incelemeler için \%4'lük paraformaldehit fiksatifi içine alındı. Rutin immünohistokimyasal takip ve boyamalar yapılarak tüm örnekler ışık mikroskobunda değerlendirildi.

Bulgular: İmmünohistokimyasal boyamalar sonucunda c-kit ve Thy-1 ekspresyonu kontrol grubuna göre tirotoksikoz grubunda belirgin düzeyde azalmış, Nanog ekspresyonu ise tirotoksikoz grubunda artmış olarak bulundu. Tirotoksikozlu sıçanlarda c-kit ve Thy-1'in azalması, tirotoksikozda stromal büyüme desteğinin azalmasına ve mikroçevre bozunumuna neden oldu.

Sonuç: Tirotoksikozda Nanog ekspresyonunun artışı, foliküler yapıları ve oositleri korumak adına dokunun katabolik süreç (tiroid hormonlarının hemen tüm hücrelerde metabolizmayı hızlandırmasına bağlı olarak) artışına rağmen reaktif olarak mikroçevreyi koruma çabası olarak yorumlandı.

Anahtar Sözcükler: c-Kit, kök hücre, Nanog, ovaryum, tirotoksikoz,

\section{Abstract}

Aim: In this study, it was aimed to investigate the possible histological changes in the ovarian structure and particularly in the oocytes, cumulus cells and granulosa cells containing thyroid hormone receptors, tissue regeneration capability and capacity in terms of stem cell markers immunohistochemically by experimentally-induced thyrotoxicosis in rats.

Materials and Methods: Two study groups were formed (eight rats for each group); 500 $\mu$ gr/kg/day 3,3',5-Triiodo-Lthyronine was injected intraperitoneally to female rats in thyrotoxicosis group during ten days. In $11^{\text {th }}$ day, all animals were anesthesized, $5 \mathrm{cc}$ blood was drawn for biochemical evaluation and then all were decapitated in order to remove ovaries. Ovaries were placed in 4\% paraformaldehyde fixative for immunohistochemical investigation. Immunohystochemical processing and staining were performed routinely and all samples were evaluated by light microscopy.

\footnotetext{
Yazışma Adresi: Fatih OLTULU

Merkezefendi Devlet Hastanesi, Histoloji ve Embriyoloji Kliniği, Manisa, Türkiye

Makalenin Geliş Tarihi: 06.06.2014 Kabul Tarihi: 04.07.2014
} 
Results: As a result of immunohistochemical staining, c-kit and Thy-1 expressions were found to be significantly decreased in the thyrotoxicosis group compared with the control group, whereas Nanog expression was increased in the thyrotoxicosis group. Decrease in c-kit and Thy-1 expression in the thyrotoxicosis group caused a reduction in the stimulatory effects of the growth factors on oocytes, cumulus and granulosa cells.

Conclusion: Decreased levels of c-kit and Thy-1 in rat model of thyrotoxicosis lead to a decrease in stromal growth support and deterioration of microenvironment. Elevated levels of Nanog expression in thyrotoxicosis was interpreted as an effort to protect the microenvironment for the sake of follicles and oocytes despite the increase in catabolic processes (as a result of increased metabolism in almost all cells due to thyroid hormones).

Keywords: c-Kit, stem cell, Nanog, ovary, thyrotoxicosis.

\section{Giriş}

Hipertiroidiye bağlı tirotoksikoz durumunda değişik organ ve sistemleri ilgilendiren bulgu ve belirtiler saptanır. Bu durumdan etkilenen organların başında da ovaryumlar gelir çünkü ovaryumlarda ki oosit, kumulus hücreleri ve granülosa hücreleri tiroid hormon reseptörleri içermektedir ve tiroid hormonu düzeylerinde oluşacak değişikliklerden direk ya da indirekt olarak etkilenmektedirler $(1,2)$. Ayrıca oositler ve kumulus hücreleri TR mRNA eksprese eder ve foliküler sıvı değişken ama anlamlı miktarda serbest T3 içerir (1). Ovaryumdaki granülosa hücrelerinde Tiroid Stimülan Hormon (TSH) reseptörlerinin varlığı ilk olarak 1993 yılında gösterilmiştir. T3 (3'-3,5 triiyodotironin) gen ekspresyonunu büyük oranda nükleer tiroid hormon reseptörleri ailesi aracılığıyla düzenler. Insan TR a geni kromozom 17 'de ve TR $\beta$ geni kromozom 3'te bulunur. Memeliler 3 değişik reseptör izoformu eksprese ederler (TR $\alpha-1, \operatorname{TR} \beta-1$, ve TR $\beta-2)$ her biri hedef genlerin transkripsiyonunu regüle ederek T3'e cevabı yönlendirebilir. İki TR izoformu, $\alpha-1$ ve TR $\beta-1$, insan mural granülosa hücrelerinde saptanmıştır (3).

Hipofizden salgılanan gonadotropinler folikül gelişimi ve farklanmasının düzenlenmesinde major rol oynarken, çeşitli hormonların ve büyüme faktörlerinin ovaryum folikül gelişiminde etkili olduğu gösterilmiştir (4).

Fare ve insan oositleri üzerinde tiroksin için spesifik bağlanma bölgelerinin tespit edilmesi tiroid hormonlarının oositler üzerinde direkt etkili olduğunu düşündürmektedir (5). Ovaryum folikülü gelişiminde ve kumulusoosit kompleksinin (COC) maturasyonunda da T3 gereklidir (6). Tirotoksikoz durumunda özellikle de granülosa hücrelerinde proliferasyon görülür (7).

Kök hücreler olarak kabul edilen primordiyal germ hücreleri, oositlerin öncülü olan oogonyumları oluşturacak olan hücrelerdir ve bu hücreler epiblast tabakasından köken alıp oluştuktan sonra gonadal kabartıya doğru göç ederler ve burada mitozla çoğalarak sayılarını artırırlar (8). Tirotoksikozda oositler üzerindeki etki mekanizmaları henüz tam olarak ortaya konulmamıştır. Çalışmamızda ovaryumda ki kök hücre belirteçleri olan Thy-1, c-kit ve Nanog kullanılarak yapılan immünohistokimyasal analizlerle incelenmesi planlanmıştır. Yetişkin dönemindeki sıçanların ovaryumlarındaki kök hücre potansiyeli ve tirotoksikoz durumunda davranış paternleri çalışmamızın üzerinde duracağı önemli bir konudur.

\section{Gereç ve Yöntem}

Deneysel çalışma, Ege Üniversitesi Tıp Fakültesi, Hayvan Etik Kurulu'nun 26 Kasım 2010 tarih 2010-153 sayılı onayı ile gerçekleştirildi. Ege Üniversitesi, Tıp Fakültesi, Deney Hayvanları Yetiştirme Merkezi'nden, ağırlıkları 180-220 gr. arasında değişen, seksüel olgunluğa ulaşmış Rattus albinus dişi sıçanlar temin edilerek Ege Üniversitesi Tıp Fakültesi Deneysel Cerrahi Bilim Dalında, $25^{\circ} \mathrm{C}$ oda ısısında, 12 saat aydınlık ve karanlık dönemlerle, serbest su ve gıda sağlanarak araştırmaya alındılar. Yem ve su günlük olarak değiştirildi.

Deney hayvanları, kontrol ve tirotoksikoz oluşturulacak gruplar olmak üzere sınıflandırılarak 2 grup oluşturuldu:

Grup 1: Kontrol dişi sıçan grubu $(\mathrm{n}=8)$ : Herhangi bir uygulama yapılmadı.

Grup 2: Tirotoksikoz dişi sıçan grubu $(\mathrm{n}=8)$ : On gün süre ile intraperitoneal $500 \mu \mathrm{gr} / \mathrm{kg} / \mathrm{gün}$ olacak şekilde 0.0025 $\mathrm{M} \mathrm{NaOH}$ (final solüsyonu olarak $\% 0.9 \mathrm{NaCl}$ kullanıldı) ile hazırlanan 3,3',5-Triiodo-L-thyronine enjekte edildi (3,3',5-Triiodo-L-thyronine (Sigma, T2877-100 mg) (911).

On birinci günde gruplardaki hayvanlara kas içi $10 \mathrm{mg} / \mathrm{kg}$ Xlasine (Bayer) ve $60 \mathrm{mg} / \mathrm{kg}$ Ketamine hydrochloride (Parke-Davis, İstanbul) uygulandı. Biyokimyasal analizler için kalp içi olarak 5 cc kan alındıktan sonra sıçanlar dekapite edilerek ovaryumları çıkarıldı ve immünohistokimyasal uygulama için \%4'lük paraformaldehit fiksatifi içine alındı. Tiroid fonksiyon testleri için alınan kan örneklerinin plazmaları ayrılarak analiz gününe kadar $-80^{\circ} \mathrm{C}$ derin dondurucuda saklandı. Tiroid fonksiyon testleri Rat Free Tri-iodothyronine, Free-T3 ELISA Kit (Cusabio Biotech Co. CSB-E05076r) ve Rat Thyroid Stimulating hormone, TSH ELISA Kit (Cusabio Biotech Co, CSB-E05115r) antijen-antikor ilişkisini, antikora bağlanmış bir enzimin aktivitesini araştırmak temeline dayanan kantitatif ölçüm yöntemi olan ELISA $(12,13)$ ile çalışıldı.

Işık mikroskobik takip için alınan dokular \%4'lük paraformaldehitte 24 saat süreyle bekletilerek fikse 
edildi. Rutin histolojik takipten sonra, alınan dokular parafine gömülerek bloklandı. Işık mikroskopik incelemeler için mikrotomda (Leica RM 2145) $5 \mu$ m'lik kesitler alınarak standart protokollere uygun olarak c-kit, Thy-1 ve Nanog ile immünohistokimyasal boyama yapıldı.

\section{Bulgular}

\section{Biyokimyasal Bulgular}

Deneysel uygulamada beklenen şekilde T3 artmış TSH'nin ise baskılandığı görüldü. 3,3',5-Triiodo-Lthyronine ile deneysel tirotoksikoz oluşturulan ve kontrol grubunda bulunan hayvanların tiroid fonksiyon testlerinin sonuçları Tablo-1'de toplu olarak gösterilmektedir.

Tablo-1. Grup I (Kontrol dişi) ve 3,3',5-Triiodo-L-thyronine Uygulanarak Tirotoksikoz Oluşturulmuş Grup II (tirotoksik dişi) Arasındaki Ortalama Tiroid Fonksiyon Test Sonuçları.

\begin{tabular}{|l|c|c|}
\cline { 2 - 3 } \multicolumn{1}{c|}{} & Grup 1 & Grup 2 \\
\hline TSH $(\mathbf{m L U} / \mathrm{mL})$ & $1.64 \pm 0.75$ & $0.051 \pm 0.06$ \\
\hline FT3 $(\mathbf{p g} / \mathbf{m L})$ & $1.59 \pm 0.38$ & $7.196 \pm 1.058$ \\
\hline
\end{tabular}

3,3',5-Triiodo-L-thyronine uygulanan grup ile kontrol grubundaki hayvanların ağırlık karşılaştırılması yapılarak, deney grubu hayvanlarda ilaç uygulanımı sonrasında tirotoksikoz gelişimine bağlı olarak tüm hücrelerde metabolizma artışının klinik bir yansıması olarak ağırlıklarında 6-27 g arasında değişen azalma saptandı (Tablo-2). Kontrol grubundaki hayvanların ağırlıklarında önemli bir azalma veya artma tespit edilmedi.

Tablo-2. Tirotoksik Dişi Grup 3,3',5-Triiodo-L-thyronine Uygulanması Öncesi ve Sonrası Ağırlık Karşılaştırıması.

\begin{tabular}{ccc}
\hline $\begin{array}{c}\text { Hayva } \\
\mathbf{n} \text { no. }\end{array}$ & $\begin{array}{c}\text { 3,3',5-Triiodo-L- } \\
\text { thyronine uygulaması } \\
\text { öncesi ağırlık }\end{array}$ & $\begin{array}{c}\text { 3,3',5-Triiodo-L- } \\
\text { thyronine uygulaması } \\
\text { sonrası ağırlık }\end{array}$ \\
\hline 1 & $185 \mathrm{~g}$ & $179 \mathrm{~g}$ \\
\hline 2 & $182 \mathrm{~g}$ & $174 \mathrm{~g}$ \\
\hline 3 & $195 \mathrm{~g}$ & $170 \mathrm{~g}$ \\
\hline 4 & $183 \mathrm{~g}$ & $161 \mathrm{~g}$ \\
\hline 5 & $198 \mathrm{~g}$ & $171 \mathrm{~g}$ \\
\hline 6 & $188 \mathrm{~g}$ & $178 \mathrm{~g}$ \\
\hline 7 & $196 \mathrm{~g}$ & $184 \mathrm{~g}$ \\
\hline 8 & $192 \mathrm{~g}$ & $176 \mathrm{~g}$ \\
\hline
\end{tabular}

\section{Immünohistokimyasal Bulgular c-Kit immünreaktivitesi}

Grup l'e (Kontrol) ait ovaryum histolojik kesitlerinde germinal epitel hücreleri, ovaryal foliküllerdeki granülosa (foliküler) hücreleri ve stromal hücrelerin c-kit ekspresyonu gösterdiği izlendi (Şekil-1A). Grup Il'ye (Tirotoksikoz) ait ovaryum histolojik kesitleri Grup । (Kontrol) ile karşılaştırıldığında germinal epitel hücreleri ve stromal hücrelerde c-kit $(+)$ hücre sayısında belirgin bir azalma izlenirken, c-kit $(+)$ stromal hücrelerde ekspresyonun oldukça kuvvetli olduğu görüldü.
Granulosa hücrelerinde ise c-kit ekspresyonu gözlenmedi (Şekil 1-B) (Tablo-3).
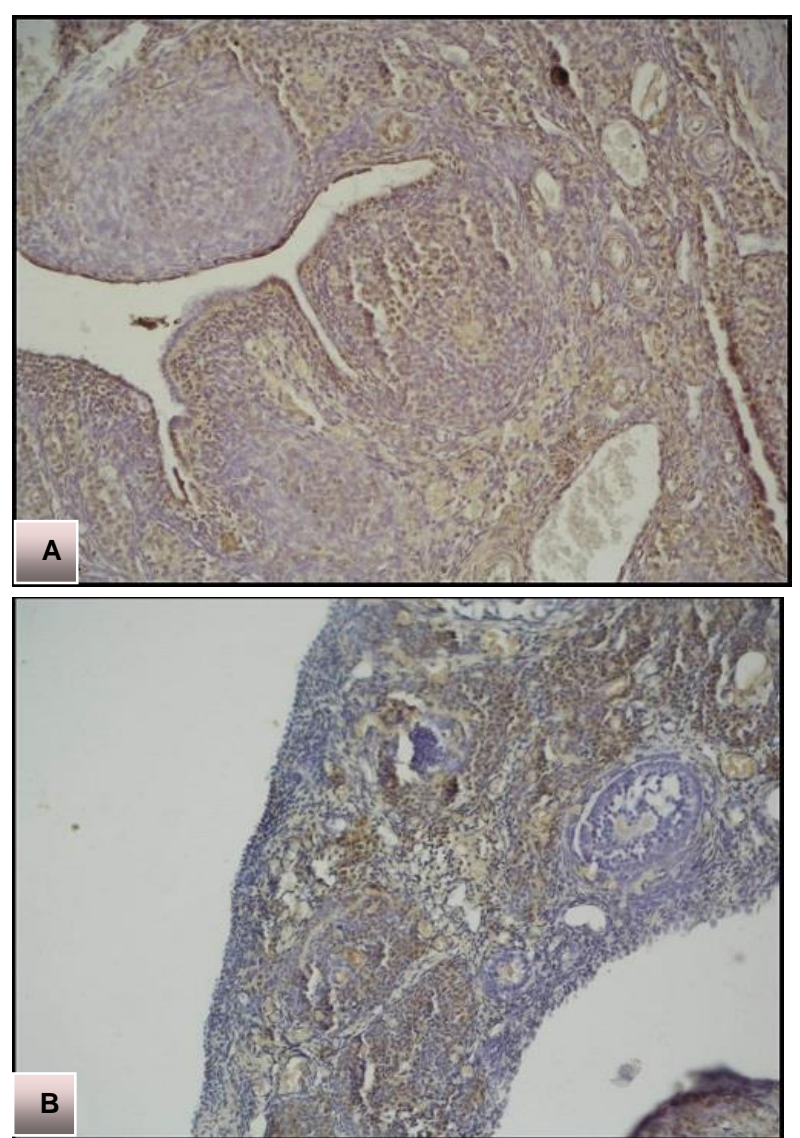

Şekil-1A,B.c-Kit immünoreaktivitesi Grup l'e (Kontrol) (A) göre Grup Il'de (tirotoksikoz) (B) azalmıştır. (Büyütme Ax10, Bx10).

Tablo-3. Ovaryuma Ait Kesitlerde Germinatif Ovaryum Epitel Hücreleri, Stromal Hücreler ve Foliküler Granulosa Hücrelerine Ait Farklı İmmünohistokimyasal Boyalar ile Boyanarak Elde Edilen İmmünoreaktif (+) Hücrelerdeki Ekspresyon Şiddetleri.

\begin{tabular}{c|c|c|c|c}
\hline \multicolumn{2}{|c|}{} & \multicolumn{3}{|c}{$\begin{array}{c}\text { Immünoreaktif (+) hücrelerde } \\
\text { ekspresyon şiddetleri }\end{array}$} \\
\cline { 3 - 5 } \multicolumn{2}{c}{ Immünoreaktivite } & $\begin{array}{c}\text { Germinatif } \\
\text { epitel } \\
\text { hücreleri }\end{array}$ & $\begin{array}{c}\text { Stromal } \\
\text { hücreler }\end{array}$ & $\begin{array}{c}\text { Granulosa } \\
\text { hücreleri }\end{array}$ \\
\hline \multirow{3}{*}{ c-kit } & Kontrol & $(++)$ & $(++)$ & $(++)$ \\
\cline { 2 - 5 } & Tirotoksikoz & $(+)$ & $(+++)$ & - \\
\hline \multirow{3}{*}{ Nanog } & Kontrol & $(+)$ & $(+)$ & - \\
\cline { 2 - 5 } & Tirotoksikoz & $(+++)$ & $(+++)$ & - \\
\hline \multirow{2}{*}{ Thy-1 } & Kontrol & $(+++)$ & $(+++)$ & - \\
\cline { 2 - 5 } & Tirotoksikoz & $(+)$ & $(+)$ & - \\
\hline
\end{tabular}

-: Boyanmamış; +: Zayıf boyanmış; ++: Orta derecede boyanmış; +++: Güçlü boyanmış.

\section{Nanog immünoreaktivitesi}

Grup l'e (Kontrol) ait histolojik kesitlerde germinal epitel hücreleri ve stromal hücrelerde Nanog ekspresyonu oldukça zayıf gözlendi (Şekil-2A). Grup Il'ye (Tirotoksikoz) ait histolojik kesitler, Grup I (Kontrol) ile 
karşılaştırıldığında, germinal epitel hücreleri ve stromal hücrelerde Nanog ekspresyonu belirgin şekilde artmış olarak izlendi (Şekil-2B). Her iki grup granülosa hücrelerinde ekspresyon gözlenmedi (Tablo-3).
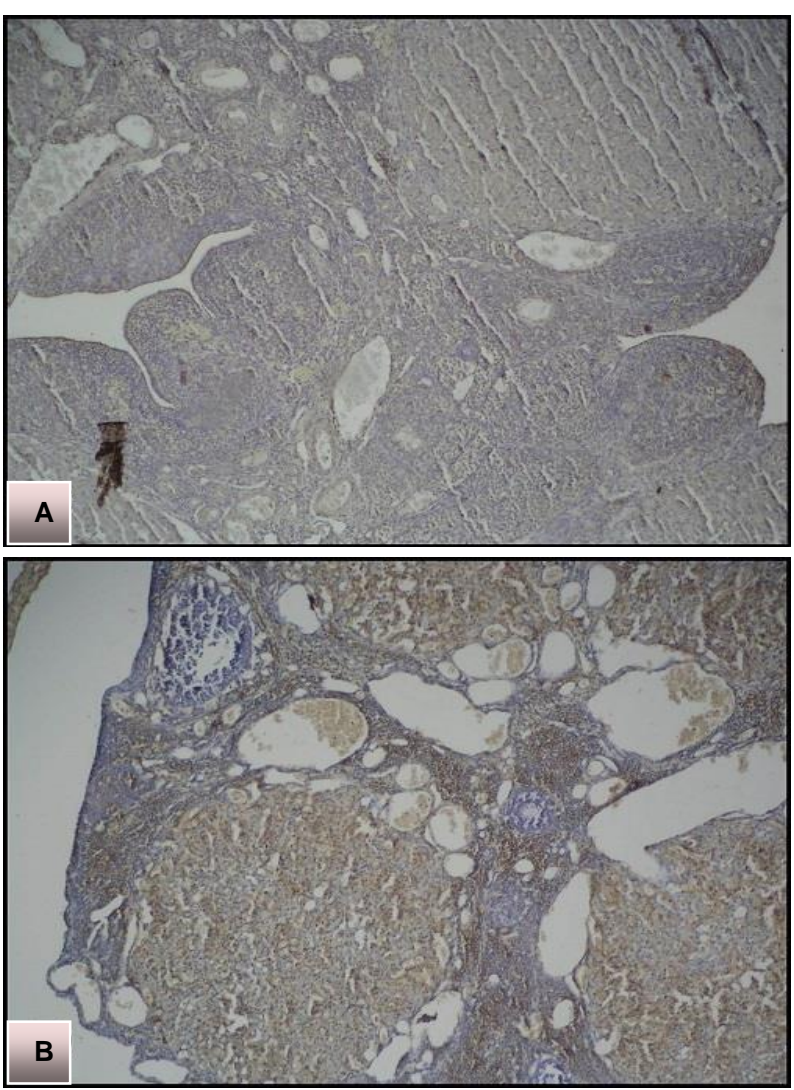

Şekil-2A,B. Nanog immünoreaktivitesi Grup l'e (Kontrol) (A) göre Grup Il'de (Tirotoksikoz) (B) artmıştır. (Büyütme Cx10, Dx10)

\section{Thy-1 immünoreaktivitesi}

Grup l'e (Kontrol) ait histolojik kesitlerde germinal epitel hücreleri ve stromal hücrelerde Thy-1 ekspresyonu gözlendi (Şekil-3A). Grup Il'ye (Tirotoksikoz) ait histolojik kesitler Grup I (Kontrol) ile karşılaştırıldığında, germinal epitel hücreleri ve stromal hücrelerde Thy-1 ekspresyonu azalmış olarak izlendi (Şekil-3B). Her iki grup granülosa hücrelerinde ekspresyon gözlenmedi (Tablo-3).

\section{Tartışma}

Tirotoksikoz, kanda tiroid hormonlarının yükselmesine bağlı olarak oluşan ve birçok sistemde bozukluğa neden olan klinik tablodur (14). Kadınlarda erkeklerden daha sık görülür (15) ve her iki cinste de en sık nedeni Graves hastalığıdır (16).

Memelilerde, fetal ve erken post-natal dönemde kadın genital sisteminin gelişimi tiroid hormonlarından bağımsızdır (17). Tiroid hormonlarının ovaryum fonksiyonları üzerine olan etki mekanizmaları tam olarak anlaşılamamıştır, çünkü tiroid hormonlarının tüm vücudu etkileyen yaygın bir etki alanı vardır (18). Ancak fare ve insan oositleri üzerinde tiroksin için spesifik bağlanma bölgelerinin bulunması nedeniyle tiroid hormonlarının, foliküler yapı ve oositler üzerinde direkt etkili olduğunu düşündürmektedir (3). Öte yandan, oositler, mural granülosa hücreleri ve kumulus hücreleri TR mRNA eksprese ederler (20). T3, insan granülosa hücre proliferasyonunu stimüle eder ve in vitro olarak hCG ile benzer etkiye sahiptir (21). Dolayısıyla, over folikülü gelişiminde ve COC maturasyonunda T3'te önemli olabilmektedir. Üstelik T3'ün etkilediği COC maturasyonu ve ovulasyonun moleküler mekanizmalarının tanımlanması hem tanı hem de IVF ve embriyo transferi için uygun koşulların tanımlanmasına da yararlı olacaktır (20). Ancak yapılan bir çalışmada olgunlaşmamış ve yetişkin farelerde, COC'nin olgunlaşması yani kumulus hücrelerinin yayılımının ve oositlerde mayoz bölünmenin başlayıp metafaz 2'ye kadar ilerlemesi sürecinin T3'den bağımsız olduğu bildirilmiştir (4). Daha önce yapılan çalışmalarda insan ve sıçan ovaryum yüzey epitel hücreleri çekirdeğinde TR $\alpha 1, T R \alpha 2$ ve TRß1 reseptörlerinin güçlü bir şekilde eksprese edildiği gösterilmiştir (22). Klinik veriler T3'ün over fonksiyonunu etkilediğini ve oosit, granülosa ve kumulus hücrelerinde uygun reseptörlerinin bulunduğunu göstermektedir (20).
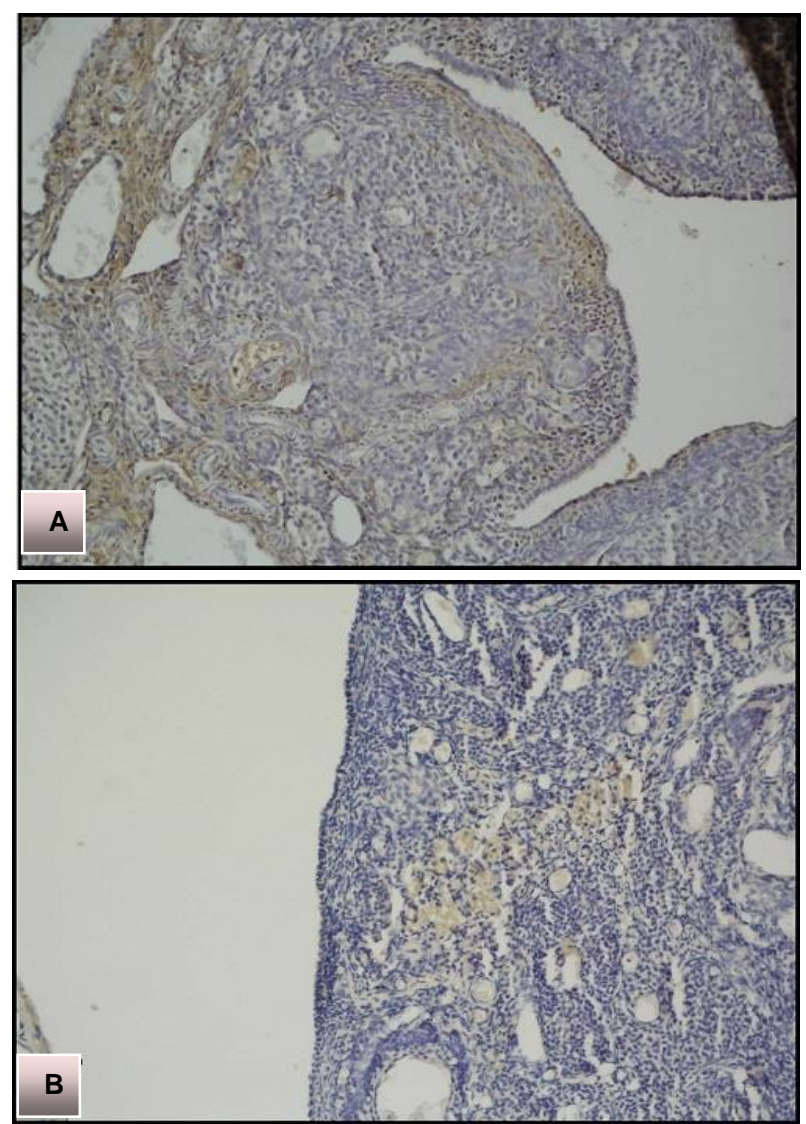

Şekil-3A,B. Thy-1 immünoreaktivitesi Grup l'e (Kontrol) (A) göre Grup Il'de (Tirotoksikoz) (B) azalmıştır. (Büyütme Cx10, Dx10).

c-Kit ligandı ile c-kit mRNA ve proteininin ovaryumda eksprese edilme paterni daha önce primatlarda, insanlarda $(23,24)$, koyunda $(25)$ ve kemirgenlerde $(26,27)$ araştırılmıştır. Genel olarak primordiyal germ 
hücreleri, teka hücreleri ve oositler c-kit reseptörünü eksprese ederken, granülosa hücreleri ve ovaryum epitel hücreleri kit ligandı üretir (28). İn situ RT-PCR yönteminden yararlanılarak koitus sonrası 16.5-17.5 gün arasında fetal fare ovaryumunun dış bölgelerinde yerleşmiş germ hücrelerinde kit ligandı ve c-kit mRNA ekspresyonu gösterilmiştir. Embriyonik gelişmenin 18.5. gününde kit ligandı ekspresyonu ovaryum medullasındaki somatik hücrelerle sınırlanmaktadır (27). Doğumda kit ligandı mRNA ve protein ekspresyonu fare ovaryumunun santral kordlarında yüksektir ve daha sonra özellikle granülosa hücreleriyle ilişkili hale geldiği bildirilmiştir $(27,29)$. Post-natal fare ovaryumlarında, kit ligandı proteini ve mRNA ekspresyonu gelişmenin tüm evrelerinde foliküllerin granülosa hücrelerinde saptanmış ancak ekspresyonu primordiyal ve primer foliküllerde ve antral foliküllerin kumulus hücrelerinde çok düşük olduğu bulunmuştur $(26,29)$. Yapılan başka bir çalışmada ise, $c$-kit mRNA ve proteini migrasyondaki mitotik primordiyal germ hücrelerinde yüksek düzeyde iken fare ve koyunların fetal hayatında mayozun ilk aşamasındaki germ hücrelerinde bulunmadığı, c-kit mRNA ekspresyonunun daha sonra diploten oositlerde geri döndüğü gösterilmiştir. c-Kit ekspresyonundaki bu duraklamanın nedeni henüz anlaşılamamıştır. Primordiyal ve sonraki evredeki oositler tek tip c-kit proteini ve mRNA'sı eksprese ederler ama ekspresyon antral foliküllerde azalır $(25,30)$. Kang ve ark. (31) tarafından yapılan bir araştırmada ise, teka hücrelerinin de c-kit protein ve mRNA'sı eksprese ettiği bildirilmiştir. İnsan örnekleri sınırlı olduğu için insan oogenezi ve folikülogenezi sırasında kit ligandı ve c-kit geçici ekspresyon düzeyleri hakkındaki bilgi pek fazla değildir. Ancak bazı araştırmaların sonuçları kadın fertilitesinde kit ligandı ve c-kit'in potansiyel rolleri hakkında bir fikir sağlamaktadır. Farelerdeki bulgulara benzer olarak, insan fetal ovaryumlarında immünohistokimyasal olarak primordiyal foliküllerdeki oositlerde c-kit'in zayıf boyandığı gösterilmiştir (32). c-Kit proteininin yeni oluşmuş insan primordiyal foliküllerinin granülosa hücrelerince de eksprese edildiğine dair bazı kanıtlar vardır (33). Kit ligandı ve c-kit proteinleri fetal ve yetişkin overlerindeki foliküllerin sadece oositlerinde saptanmış ancak granülosa hücrelerinde ikisi de bulunamamıştır (34). Ancak başka bir araştırmada ise, kit ligandı proteininin insan fetal overlerinde primordiyal, pre-antral ve erken antral foliküllerin granülosa hücrelerinde immünolokalizasyon gösterdiği tespit edilmiştir (33). Söz konusu araştırmamızda ise, incelediğimiz kontrol grubu yetişkin sıçan ovaryumlarında c-kit immünoekspresyonunun germinatif epitel hücrelerinde, preantral ve antral foliküllerin granülosa hücrelerinde ve özellikle stromal hücrelerde belirgin olduğu saptanmıştır. Tirotoksikoz grubu yetişkin ovaryum kesitlerinde c-kit immünoekspresyonu incelendiğinde, germinal epitel ve stromal hücrelerde c-kit pozitif hücre sayısında belirgin bir azalma görülmesine rağmen stromal hücrelerdeki ekspresyonun oldukça kuvvetli olduğu, granülosa hücrelerinde ise c-kit ekspresyonunun olmadığı tespit edilmiştir.

Thy-1 mezenşimal hücre proliferasyonunu uyarıcı etkiye sahiptir ancak ovaryum kanseri ve nazofaringeal kanser gibi bazı kanser türlerinde de proliferasyonu baskılayarak tümör supresoru olarak tanımlanmaktadır (35). Thy-1 ekspresyonu gelişimsel olarak nöronlarda ve ovaryum folikül hücrelerinde düzenlenmektedir (36). Bukovsky (37) tarafından, primer foliküllerde ve çevresindeki stromal hücreler ile vasküler perisitlerde immünoekspresyon gösterilmiştir. Preantral ve antral foliküllerin büyümesinde, aktive makrofajlar ve tekal vasküler perisitlerden Thy-1'in aşırı sekresyonu eşlik eder (38). Menstrüel siklus sırasında bir folikül seçilip dominant hale gelir ve diğerleri atreziye uğrar. Seçilen folikülün hangi mekanizmayla atreziden korunduğu ise belirsizdir. Foliküler seçim sırasında seçilen folikülün (dominant) regrese olan foliküllere göre (nondominant) anlamlı tekal gelişme geriliği gösterdiği ve bunun tekal tabakada hızlandırıımış bir differansiasyona bağlı olduğu gösterilmiştir. Bu durumun ise, büyük olasılıkla Thy-1 pozitif perisit aktivitesinin otonomik innervasyonla geçici olarak inhibe olmasına bağlı olduğu düşünülmektedir (39). Araştırmamızda Thy-1 kontrol grubu ovaryum kesitlerinde germinal epitel ve stromal hücrelerde kuvvetli ekspresyon gözlenirken tirotoksikoz grubunda ise azaldığı saptanmıştır. Bulgular tirotoksikozun Thy-1 ekspresyonunu baskıladığını düşündürmektedir. Öte yandan Thy-1, birçok proteinin bağlanması için membranda bulunan, yapısal olarak antikora benzeyen ve aynı zamanda da bir adezyon molekülüdür. Thy-1, ortamda bcl-2 olsa dahi apoptozisi baskılarken bir yandan da fibrozisi artırır. Hipertirodili grupta Thy-1 ekspresyonu azalmıştır. Bu genel katabolik süreçte membrandaki birçok proteinle birlikte Thy-1'inde katabolizmasına bağlı olabilir. Thy-1'in azalması da bir yandan hücreleri apoptozise götürürken, bir yandan da fibroblast growth faktör gibi çalıştığı için fibrozisi azaltmış olabilir.

İlk trimesterde fetal ovaryumlarda Nanog ekspresyonunun gelişimsel paterni gösterilmiştir ancak geç evrelerde ekspresyon düzeyinin zayıf olduğu belirtilmiştir (40). İkinci trimesterde ise Nanog ekspresyonunun bulunmadığı bildirilmektedir (41). Yedi haftalık embriyoda Nanog pozitif hücreler medulla ve korteks bölgesinde eşit olarak dağılmış bir şekilde gonadın tümünde görülmektedir. On birinci haftada ise Nanog pozitif hücre sayısı azalmış ve primer olarak dış kortekste yerleşmişlerdir (40). İkinci trimesterin başında Nanog pozitif germ hücre sayısı, kortekste daha yüksek olarak saptanmıştır $(40,42)$. Araştırmamızda tirotoksikoz grubuna ait ovaryum histolojik kesitlerinde kontrol grubuna göre, germinal epitel hücreler ve dış korteksteki stromal hücrelerde kuvvetli Nanog ekspresyonu gözlenmiştir. Nanog 
ekspresyonunun kortikal stromal hücrelerdeki varlığı literatür bilgileri ile uyumlu bulunmuştur.

\section{Sonuç}

c-Kit, CD117 adı ile bilinen stromal nöroendokrin büyüme faktörü reseptörünü kodlar. Tirotoksikozlu sıçanlarda c-kit protein ekspresyonu azalmıştır. Buna bağlı büyüme faktörü reseptör membran ekspresyonu da azalmıştır. Bu bulgular tirotoksikozda stromal büyüme desteğinin azalmasına ve mikroçevre bozunumuna katkıda bulunmuştur.

Nanog özellikle stromal fibroblastların diferansiasyonu için gerekli olan bir transkripsiyon faktörüdür. Bu çalışmaya ait bulgular tirotoksikozda ovaryumdaki Nanog ekspresyonunun artışı, foliküler yapıları ve oositleri korumak adına dokunun katabolik süreç artışına rağmen reaktif olarak oositleri çevreleyen mikroçevreyi koruma çabası olarak yorumlanmıştır.

\section{Kaynaklar}

1. Zhang SS, Carrillo AJ, Darling DS. Expression of multiple thyroid hormone receptor mRNA in human oocytes, cumulus cells, and granulosa cells. Mol Hum Reprod 1997;3(7):555-62.

2. Wang C, Crapo LM. The epidemiology of thyroid disease and implications for screening. Endocrinol Metab Clin North Am 1997;26(1):189-218.

3. Wakim AN, Polizotto SL, Buffo MJ, Marrero MA, Burholt DR. Thyroid hormones in human follicular fluid and thyroid hormone receptors in human granulosa cells Fertil Steril 1993;59(6):1187-90.

4. Cecconi S, Rucci N, Scaldaferri ML, et al. Thyroid hormone effects on mouse oocyte maturation and granulosa cell aromatase activity. Endocrinology 1999;140(4):1783-8.

5. Krassas GE, Poppe K, Glinoer D. Thyroid function and human reproductive health. Endocr Rev 2010;31(5):702-55.

6. Van Voorhis BJ, Neff TW, Syrop CH, Chapler FK. Primary hypothyroidism associated with multicystic ovaries and ovarian torsion in adult. Obstet Gynecol 1994;83(5 Pt 2):885-7.

7. Maruo T, Hayashi M, Matsuo H, Yamamoto T, Okada H, Mochizuki M. The role of thyroid hormone as biological amplifier of the actions of follicle-stimulating hormone in the functional differentiation of cultured porcine granulosa cell. Endocrinology 1987;121(4):1233-41.

8. Dalçık H, Yıldırım M (Çeviri ed). Klinik Yönleriyle İnsan Embriyolojisi. 8. Baskı. İstanbul: Nobel Matbaacııı; 2009:173-283.

9. Zamoner A, Barreto KP, Filho DW, et al. Hyperthyroidism in the developing rat testis is associated with oxidative stress and hyperphosphorylated vimentin accumulation. Mol Cell Endocrinol 2007;267(1-2):116-26.

10. O'Neal P, Alamdari N, Smith I, Poylin V, Menconi M, Hasselgren PO. Experimental hyperthyroidism in rats increases the expression of the ubiquitin ligases atrogin-1 and MuRF1 and stimulates multiple proteolytic pathways in skeletal muscle. J Cell Biochem 2009;108(4):963-73.

11. Faraone-Mennella MR, Ferone A, Marino L, et al. Poly(ADP-ribosyl)ation of proteins and germ cell development in hyperthyroid rat testes. Mol Cell Biochem 2009;323(1-2):119-29.

12. Ismat F, Munawar A, Affia T, et al. Antithyroid activity of some 6-(alkylsulfanyl)-9H-purines. J Serb Chem Soc 2011;76(10)135564.

13. Ismat $F$, Munawar A, Affia T, Asmatullah A, Khan MA. Assessment of antithyroid activity of 2,8-disulfanyl-1, 9-dihydro-6H-purin6-one in vitro and in vivo. Med Chem Res 2011; DOI 10.1007/s00044-011-9608-2 (published online).

14. Erdoğan G. Koloğlu Endokrinoloji - Temel ve Klinik. 2.Baskı. Adana: Nobel Yayınevi; 2005:155-280.

15. Tunbridge WM, Evered DC, Hall R, et al. The spectrum of thyroid disease in a community: The Whickham survey. Clin Endocrinol 1977;7(6):481-93.

16. Cramer DW, Sluss PM, Powers RD, et al. Serum prolactin and TSH in an in-vitro fertilization population: Is there a link between fertilization and thyroid function? J Assist Reprod Genet 2003;20(6):210-5.

17. Longcope C. The male and female reproductive system in hypothyroidism. In: Ingbar SH, Bravermann LE (eds). The Thyroid. Philadelphia: Lippincott; 1991:1052-5.

18. Cle'ment $\mathrm{K}$, Viguerie $\mathrm{N}$, Diehn $\mathrm{M}$, et al. In vivo regulation of human skeletal muscle gene expression by thyroid hormone. Genome Res 2002;12(2):281-91.

19. Krassas GE, Poppe K, Glinoer D. Thyroid function and human reproductive health. Endocr Rev 2010, 31(5);702-55.

20. Zhang SS, Carrillo AJ, Darling DS. Expression of multiple thyroid hormone receptor mRNAs in human oocytes, cumulus cells, and granulosa cells, Mol Human Reprod 1997;3(7):555-62.

21. Goldman S, Dirnfeld M, Gonen Y, Koifman M, Lissak A, Abramovici H. Different morphology and proliferative ability of cumulus and granulosa cells originating from cystic follicles aspirated from stimulated in vitro fertilization patients. Fertil Steril 1993;59(3):601-5.

22. Rae MT, Niven D, Ross A, et al. Steroid signalling in human ovarian surface epithelial cells: The response to interleukin-1 determined by microarray analysis. J Endocrinol 2004;183(1):19-28.

23. Horie K, Fujita J, Takakura K, et al. The expression of c-kit protein in human adult and fetal tissues. Hum Reprod 1993;8(11);1955-62.

24. Gougeon A, Busso D. Morphologic and functional determinants of primordial and primary follicles in the monkey ovary. Mol Cell Endocrinol 2000;163(1-2):33-42.

25. Clark DE, Tisdall DJ, Fidler AE, McNatty KP. Localization of mRNA encoding c-kit during the initiation of folliculogenesis in ovine fetal ovaries. J Reprod Fertil 1996;106(2):329-35. 
26. Motro B, Bernstein A. Dynamic changes in ovarian c-kit and steel expression during the estrous reproductive cycle. Dev Dyn 1993;197(1):69-79.

27. Doneda L, Klinger FG, Larizza L and De Felici M. KL/KIT co-expression in mouse fetal oocytes. Int J Dev Biol 2002;46(8):101521.

28. Hutt KJ, Mc Laughlin EA, Holland MK. Kit ligand and c-Kit have diverse roles during mammalian oogenesis and folliculogenesis. Mol Hum Reprod 2006;12(2):61-9.

29. Manova K, Huang EJ, Angeles M. The expression pattern of the c-kit ligand in gonads of mice supports a role for the c-kit receptor in oocyte growth and in proliferation of spermatogonia. Dev Biol 1993;157(1):85-99.

30. Manova K, Bachvarova RF. Expression of $\mathrm{c}$-kit encoded at the $\mathrm{W}$ locus of mice in developing embryonic germ cells and presumptive melanoblasts. Dev Biol 1991;146(2):312-24.

31. Kang JS, Lee CJ, Lee JM, Rha JY, Song KW, Park MH. Follicular expression of c-Kit/SCF and inhibin-alpha in mouse ovary during development. J Histochem Cytochem 2003;51(11):1447-58.

32. Robinson LL, Gaskell TL, Saunders PTK, Anderson RA. Germ cell specific expression of c-kit in the human fetal gonad. Mol Hum Reprod 2001;7(9):845-52.

33. Hoyer PE, Byskov AG, Mollgard K. Stem cell factor and c-kit in human primordial germ cells and fetal ovaries. Mol Cell Endocrinol 2005;234(1-2):1-10.

34. Abir R, Fisch B, Jin S, Barnnet M, Kessler-Icekson G, Ao A. Expression of stem cell factor and its receptor in human fetal and adult ovaries. Fertil Steril 2004;8(Suppl 3):1235-43

35. Rege TA, Hagood JS. Thy-1, a versatile modulator of signaling affecting cellular adhesion, proliferation, survival, and cytokine/growth factor responses. Biochim Biophys Acta 2006;1763(10):991-9.

36. Xue GP, Calvert RA, Morris RJ. Expression of the neuronal surface glycoprotein Thy-1 is under posttranscriptional control, and is spatially regulated, in the developing olfactory system. Development 1990;109(4):851-64.

37. Bukovsky A, Caudle MR, Svetlikova M, Upadhyaya NB. Origin of germ cells and formation of new primary follicles in adult human ovaries. Reprod Biol Endocrinol 2004;28(2):20-2.

38. Bukovsky A, Caudle MR, Keenan JA, Wimalasena J, Foster JS, Van Meter SE. Quantitative evaluation of the cell cycle-related retinoblastoma protein and localization of Thy-1 differentiation protein and macrophages during follicular development and atresia, and in human corpora lutea. Biol Reprod 1995;52(4):776-92.

39. Bukovsky A, Caudle MR, Svetlikova M, Wimalasena J, Ayala ME, Dominguez R. Oogenesis in adult mammals, including humans. Endocrine 2005;26(3):301-6.

40. Kerr CL, Hill CM, Blumenthal PD, Gearhart JD. Expression of pluripotent stem cell markers in the human fetal ovary. Hum Reprod 2008;23(3):589-99.

41. Hoei-Hansen CE, Kraggerud SM, Abeler VM, Kaern J, Rajpert-De Meyts E, Lothe RA. Ovarian dysgerminomas are characterised by frequent KIT mutations and abundant expression of pluripotency markers. Mol Cancer 2007;2(6):12-4.

42. Stoop H, Honecker F, Cools M, de Krijger R, Bokemeyer C, Looijenga LH. Differentiation and development of human female germ cells during prenatal gonadogenesis: An immunohistochemical study. Hum Reprod 2005;20(6):1466-76. 